\author{
Al-wardah: Jurnal Kajian Perempuan, Gender dan Agama \\ Volume: 12 Nomor: 2 \\ ISSN: 1907-2740, E-ISSN: 2613-9367 \\ DOI: $\mathrm{xxx} \mathrm{xxxx} \mathrm{xxxx}$
}

\title{
KONSEP DASAR MANAJEMEN PENDIDIKAN ISLAM
}

\author{
Marwan Syaban \\ Universitas Khairun Ternate, Indonesia \\ marwansyaban@gmail.com
}

\begin{abstract}
Abstrak
Manajemen pendidikan Islam proses pemanfaatan semua sumber daya melalui bantuan orang lain dan bekerjasama dengannya, agar tujuan bersama bisa dicapai secara efektif, efesien, dan produktip. Sedangkan Pendidikan Islam merupakan proses transinternalisasi nilai-nilai Islam kepada peserta didik sebagai bekal untuk mencapai kebahagiaan dan kesejahteraan di dunia dan di akhirat. Tujuan manajemen pendidikan Islam adalah bahwa segala hal dan proses-proses yang berlangsung dapat benar-benar dikelola dengan baik sehingga proses pendidikan dapat benar-benar terwujud sesuai ajaran Islam dan. upaya pencapaian tujuan pendidikan Islam dapat lebih mudah terwujud. Ruang lingkup praktik manajemen pendidikan Islam meliputi manajemen kelembagaan dan program pendidikan Islam serta aspek spirit Islam melekat pada setiap aktivitas pendidikan. Sedangkan mengenai prinsip manajemen pendidikan Islam setidaknya ada 14 , diantaranya; pembagian kerja, kejelasan dalam wewenang dan tanggung jawab, disiplin, kesatuan komando, kesatuan arah, lebih memprioritaskan kepentingan umum/organisasi daripada kepentingan pribadi, pemberian kontra prestasi, sentralisasi, rantai skalar, tertib, pemerataan, stabilitas dalam menjabat, inisiatif, dan semangat kelompok.
\end{abstract}

Kata Kunci: Aktivitas Pendidikan Islam

\begin{abstract}
Islamic education management processes the use of all resources through the help of others and collaborates with them, so that shared goals can be achieved effectively, efficiently and productively. Whereas Islamic Education is the process of internalizing Islamic values to students as a provision to achieve happiness and prosperity in the world and in the here after. The purpose of Islamic education management is that all things and processes that take place can be truly managed so that the educational process can truly be realized according to Islamic teachings and. efforts to achieve the goals of Islamic education can be more easily realized.The scope of Islamic education management practices includes institutional management and Islamic education programs as well as aspects of Islamic spirit inherent in every educational activity. Whereas there are at least 14 principles of management of Islamic education, including;
\end{abstract}


division of labor, clarity in authority and responsibility, discipline, command unity, unity of direction, prioritizing public/organizational interests rather than personal interests, giving contra-achievements, centralization, scalar, orderly, even distribution, stability in office, initiative and group spirit.

Key words: Islamic Education Activities

\section{A. Pendahuluan}

Dewasa ini lembaga pendidikan Islam berkembang sebagai lembaga yang semakin kompleks sehingga ini membutuhkan organisasi yang tertata dengan baik dan benar. Kompleksitas lembaga pendidikan Islam terutama terlihat akan kebutuhan pengelolaan pelaksanaan pendidikan dengan pendekatan manajeman. Itulah kebutuhan untuk menggunakan pendekatan ilmu manajemen di lembaga pendidikan hususnya lembaga pendidikan Islam menjadi mutlak. Sehingga perkembangan administarsi pendidikan menjadi bagian yang menarik bagi kalangan praktisi dan ahli pendidikan sampai sekarang ini.

Berdasarkan latar belakang di atas, maka penulis merumuskan masalah sebagai berikut :

1. Apa pengertian manajemen pendidikan Islam ?

2. Bagaimana dasar-dasar manajemen pendidikan Islam ?

3. Apa tujuan manajemen pendidikan Islam?

4. Bagaimana ciri dan kegunaan manajemen pendidikan Islam ?

Berdasarkan rumusan masalah diatas, maka penulis dapat menentukan tujuan pembahasan sebagai berikut:

1. Untuk dapat mengetahui pengertian Manajemen Pendidikan Islam.

2. Untuk dapat mengetahui dasar-dasar Manajemen Pendidikan Islam.

3. Untuk dapat mengetahui tujuan Manajemen Pendidikan Islam.

4. Untuk Menegetahui ciri dan kegunaan Manajemen Pendidikan Islam.

\section{B. Pembahasan}

\section{Manajemen Pendidikan Islam}

\section{a. Pengertian Manajemen}

Secara etimologis kata manajemen berasal dari bahasa Inggris yang merupakan terjemahan langsung dari kata management yang berarti pengelolaan, ketata laksanaan atau tata pimpinan (Anonim, 2011). Sementara dalam kamus Inggris Indonesia karangan John M.Echols dan Hasan Shadily Management berasal dari akar kata to manage yang berarti mengurus, mengatur, melaksanakan, mengelola dan 
memperlakukan. Dalam kamus besar Bahasa Indonesia (KBBI) Online, Manajemen artinya penggunaan sumber daya secara efektif untuk mencapai sasaran (Anonim, 2015).

Dalam bahasa Arab istilah manajemen diartikan sebagai an-nizam atau attanzim, yang merupakan suatu tempat untuk menyimpan segala sesuatu dan penempatan segala sesuatu pada tempatnya. Allah berfirman dalam Al-Qur'an surah Al-Sajdah: 5

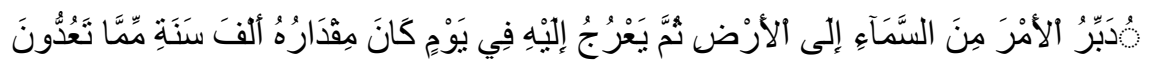

Artinya : Dia mengatur urusan dari langit ke bumi, kemudian (urusan) itu naik kepadanya dalam satu hari yang kadarnya adalah seribu tahun menurut perhitunganmu (Al Sajdah : 05)

Dari isi kandungan ayat di atas dapatlah diketahui bahwa Allah swt adalah pengatur alam (manager). Keteraturan alam raya ini merupakan bukti kebesaran Allah swt dalam mengelola alam ini. Namun, karena manusia yang diciptakan Allah SWT telah dijadikan sebagai khalifah di bumi, maka dia harus mengatur dan mengelola bumi dengan sebaik-baiknya sebagaimana Allah mengatur alam raya ini.

Pengertian tersebut dalam skala aktivitas juga dapat diartikan sebagai menertibkan, mengatur dan berpikir yang dilakukan oleh seseorang, sehingga ia mampu mengemukakan, menata dan merapikan segala sesuatu yang ada disekitarnya, Sedangkan secara terminology banyak defenisi yang dikemukakan oleh para ahli, diantaranya adalah: P.Siagian mengartikan manajemen sebagai kemampuan atau ketrampilan untuk memperoleh suatu hasil dalam rangka mencapai tujuan melalui kegiatan-kegiatan orang lain mengetahui prinsip-prinsipnya serta menjadikan hidup selaras dan serasi dengan yang lainnya (Siagan, 1990). Manajemen adalah suatu usaha, merencanakan, mengorganisir, mengarahkan, mengakomodir serta mengawasi kegiatan dalam suatu organisasi agar tercapai tujuan organisasi secara efisien dan efektif (Manaf, 2001).

Marry Papker Follet, "Manajemen sebagai seni untuk mendapatkan sesuatu melalui sikap dan ketrampilan tertentu (Wahjosomidjo, 2001). James A.F.Stoner mengemukakan bahwa manajemen adalah proses untuk mencapai tujuan yang telah ditetapkan. Manajemen sebagai ilmu dan seni mengatur proses pendayagunaan sumber daya manusia dan sumber daya lainnya secara efisien, efektif dan produktif dalam mencapai suatu tujuan (Rivai, 2006). Berdasarkan pengertian-pengertian tersebut, maka penulis berkesimpulan bahwa manajemen dapat diartikan sebagai suatu proses dengan menggunakan sumber daya manusia dan sumber daya lainnya untuk mencapai suatu tujuan. 


\section{b. Pengertian Pendidikan Islam}

Untuk memberikan pengertian pendidikan Islam, lebih bijaknya kalau melihat konsep pendidikan terlebih dahulu.. Pendidkan dalam bahasa Indonesia berasal dari kata "didik" dengan memberinya awalan "pe" dan akhiran '"an" yang mengandung arti "perbuatan". Istilah pendidikan semula berasal dari bahasa Yunai yaitu paedagogie yang berarti bimbingan kepada anak. istilah ini diterjemahkan ke dalam bahasa Inggris dengan education yang berarti pengembangan atau bimbingan (Mustali, 2014). Dalam kamus besar bahasa Indonesia on-line, pendidikan adalah proses perubahan sikap dan tata laku seseorang atau kelompok orang dalam usaha mendewasakan manusia melalui upaya pengajaran dan pelatihan, proses, cara dan perbuatan mendidik.

Undang-undang No.20 Tahun 2003 tentang sistim pendidikan nasional mendefenisikan pendidikan sebagai suatu usaha sadar dan terencana untuk mewujudkan suasana belajar dan proses pembelajaran agar peserta didik secara aktif mengembangkan potensi dirinya untuk memiliki kekuatan spriritual keagamaan pengendalian diri, kepribadian, kecerdasan, ahlak mulia serta ketrampilan yang diperlukan dirinya, masyarakat bangsa dan negara.

Dalam bahasa Arab pendidikan disebut tarbiyah yang diambil dari kata Rabba-yarubbu-Tarbiyah yang bermakna tumbuh dan berkembang atau bertambah yaitu upaya menumbuh kembangkan atau menambah ( menghidupkan) potensi manusia. Sebagai mana firman Allah dalam Al-Qur'an surat Al-Is'ra ayat 24

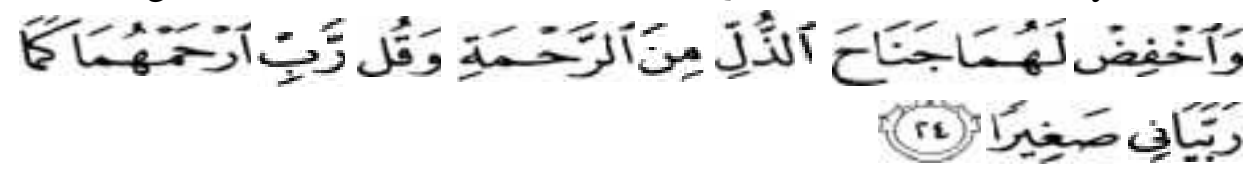

yang artinya : Dan hendaklah engkau merendahkan diri kepada keduanya karena belas kasihan dan kasih sayangmu, dan doakanlah ( untuk mereka, dengan berkata ): "Wahai Tuhanku! Cucurilah rahmat kepada mereka berdua sebagaimana mereka telah mencurahkan kasih sayangnya, memelihara dan mendidikku semasa kecil."

Ditinjau dari segi terminology, banyak batasan dan pandangan yang dikemukakan para ahli. Diantaranya ada yang mengemukakan pengertian pendidikan Islam sebagai berikut:

1. Pendidikan Islam pada dasarnya adalah pendidikan yang bertujuan untuk membentuk pribadi Muslim seutuhnya, mengembangkan seluruh potensi manusia baik yang berbentuk jasmani maupun rohani (Daulay, 2004).

2. Menurut Zuhairini Pendidikan Agama Islam berarti "usaha-usaha secara sistematis dan pragmatis dalam membantu anak didik agar mereka hidup sesuai dengan ajaran Islam (Zuhaerini, 1983). 
3. pendidikan islam sebagai bimbingan yang diberikan oleh seseorang agar ia berkembang secara maksimal sesuai dengan ajaran Islam (Tafsir, 2005).

Dari beberapa definisi di atas, maka penulis berkesimpulan bahwa yang dimaksud Pendidikan Agama Islam adalah suatu aktivitas atau usaha-usaha tindakan dan bimbingan yang dilakukan secara sadar dan sengaja serta terencana yang mengarah pada terbentuknya kepribadian anak didik yang sesuai dengan norma-norma yang ditentukan oleh ajaran agama. Terbentuknya kepribadian yakni pendidikan yang diarahkan pada terbentuknya kepribadian muslim. Kepribadian muslim adalah pribadi yang ajaran Islam nya menjadi sebuah pandangan hidup, sehingga cara berpikir, merasa, dan bersikap sesuai dengan ajaran Islam.

\section{c. Pengertian Manajemen Pendidikan Islam}

Pengertian manajemen dan pendidikan Islam telah tersebut diatas. Sedangkan Manajemen pendidikan Islam menurut para pakar diantaranya ialah; Sulistyorini menulis bahwa manajemen pendidikan Islam adalah suatu proses penataan/pengelolaan lembaga pendidikan Islam yang melibatkan sumberdaya manusia muslim dan non manusia dalam menggerakkannya untuk mencapai tujuan pendidikan Islam secara efektif dan efisien (Sulistyorini, 2006). Sementara itu Mujamil Qomar mengartikan sebagai suatu proses pengelolaan lembaga pendidikan Islam secara Islami dengan cara menyiasati sumber-sumber balajar dan hal-hal lain yang terkait untuk mencapai tujuan pendidikan Islam secara efektif dan efisien (Qomar, 2008). Manajemen harus mengutamakan pengelolaan secara Islami, sebab disinilah yang membedakan antara manajemen Islam dengan menejemen umum.

Manajemen pendidikan Islam sebagaimana dinyatakan Ramayulis adalah proses pemanfaatan semua sumber daya yang dimiliki (ummat Islam, lembaga pendidikan atau lainnya) baik perangkat keras maupun lunak. Pemanfaatan tersebut dilakukan melalui kerjasama dengan orang lain secara efektif, efisien, dan produktif untuk mencapai kebahagiaan dan kesejahteraan baik di dunia maupun di akhirat.

Berdasarkan uraian di atas maka dapat di simpulkan bahwa manajemen pendidikan Islam proses pemanfaatan semua sumber daya melalui bantuan orang lain dan bekerjasama dengannya, agar tujuan bersama bisa dicapai secara efektif, efesien, dan produktip. Sedangkan Pendidikan Islam merupakan proses trans internalisasi nilainilai Islam kepada peserta didik sebagai bekal untuk mencapai kebahagiaan dan kesejahteraan di dunia dan di akhirat.

\section{Manajemen Pendidikan Islam}

Dasar manajemen pendidikan Islam secara garis besar ada 3 (tiga) yaitu: AlQur'an, As-Sunnah serta perundang-undang yang berlaku di Indonesia. 


\section{a. Al-Qur'an}

Banyak Ayat-ayat Al-Qur'an yang bisa menjadi dasar tentang manajemen pendidikan Islam. Ayat-ayat tersebut bisa dipahami setelah diadakan penelaahan secara mendalam. Di antara ayat-ayat Al-Qur'an yang dapat dijadikan dasar manajemen pendidikan Islam adalah sebagai berikut:

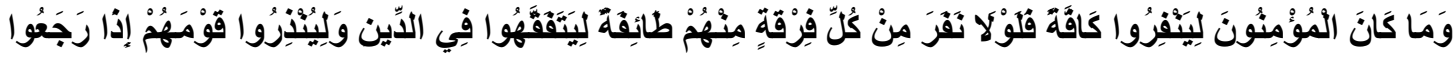

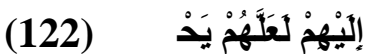

Tidak sepatutnya bagi mukminin itu pergi semuanya (ke medan perang). mengapa tidak pergi dari tiap-tiap golongan di antara mereka beberapa orang untuk memperdalam pengetahuan mereka tentang agama dan untuk memberi peringatan kepada kaumnya apabila mereka telah kembali kepadanya, supaya mereka itu dapat menjaga dirinya (QS. At-Taubah: 122).

Dengan demikian dapat disimpulkan bahwa Islam menegaskan tentang pentingnya manajemen, di antaranya manajemen pendidikan, lebih khusus lagi manajemen sumber daya manusia.

\section{b. As-Sunnah}

Rasulullah SAW adalah juru didik dan beliau juga menjunjung tinggi terhadap pendidikan dan memotivasi umatnya agar berkiprah dalam pendidikan dan pengajaran. Rasulullah SAW bersabda:

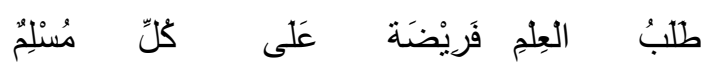

"M enuntut ilmu itu diwajibkan bagi setiap orang Islam". (Riwayat Ibnu Majah, Al-Baihaqi, Ibnu Abdil Barr, dan Ibnu Adi, dari Anas bin Malik).

Berdasarkan pada hadits di atas, Rasulullah SAW memiliki perhatian yang besar terhadap pendidikan.

\section{c. Perundang-Undangan yang Berlaku di Indonesia}

Dalam UU No. 20 Tahun 2003 tentang Sistem Pendidikan Nasional disebutkan dalam Pasal 30 ayat 1 bahwa: "Pendidikan keagamaan diselenggarakan oleh pemerintah dan/atau kelompok masyarakat dari pemeluk agama, sesuai dengan peraturan perundangundangan". Disebutkan pula dalam Pasal 30 ayat 2 bahwa "Pendidikan keagamaan berfungsi menyiapkan peserta didik menjadi anggota masyarakat yang memahami dan mengamalkan nilai-nilai ajaran agamanya dan/atau menjadi ahli ilmu agama" 


\section{Tujuan Manajemen Pendidikan Islam}

Manajemen pendidikan adalah manajemen yang diterapkan dalam pengembangan pendidikan. Dalam arti ia merupakan seni dan ilmu mengelola sumber daya pendidikan Islam untuk mencapai tujuan pendidikan Islam secara efektif dan efisien. Bisa juga diartikan sebagai proses perencanaan, pengorganisasian, pengarahan dan pengendalian sumber daya pendidikan Islam untuk mencapai tujuan pendidikan Islam secara efektif dan efesien. Manajemen pendidikan lebih bersifat umum untuk semua aktifitas pendidikan pada umumnya, sedangkan manajemen pendidikan lebih khusus lagi mengarah pada manajemen yang diterapkan dalam pengembangan pendidikan Islam. Dalam arti bagaimana menggunakan dan mengelola sumber daya pendidikan Islam secara efektif dan efisien untuk mencapai tujuan pengembangan, kemajuan dan kualitas proses dan hasil pendidikan Islam itu sendiri. Sudah barang tentu aspek manager dan leader yang Islami atau dijiwai oleh ajaran dan nilai-nilai Islam dan/atau yang berciri khas Islam, harus melekat pada manajemen pendidikan Islam.

Dalam menjalankan setiap kegiatan tentunya dibutuhkan suatu usaha yang efisien dan ekonomis karena alasan tersebut begitu dipegang teguh dalam setiap sistem organisasi. Dengan kata lain tingkat pemborosan atau penyalahgunaan sangatlah bertolak belakang dengan prinsip-prinsip organisasi. Dengan mengetahui identitasnya dan juga kebutuhan tentang manajemen tentu akan dapat menentukan apa tujuan manajemen itu sendiri. Mengingat manajemen sebenarnya adalah alat dari suatu organisasi, maka adanya alat tersebut tentunya memiliki tujuan.

Menurut Susilo Martoyo ,tujuan manajemen pendidikan Islam adalah agar segenap sumber, peralatan ataupun sarana yang ada dalam suatu organisasi tersebut dapat digerakkan sedemikian rupa sehingga dapat menghindarkan sampai tingkat seminimal mungkin segenap pemborosan waktu, tenaga, materil, dan uang guna mencapai tujuan organisasi yang telah ditetapkan terlebih dahulu (Martoyo, 1988). Tujuan Manajemen Pendidikan Islam adalah menggunakan dan mengelola seumber daya pendidikan Islam secara efektif dan efisien untuk mencapai tujuan, pengembangan, kemajuan dan kualitas proses dan hasil pendidikan Islam itu sendiri.

Dari pengertian diatas maka dapat disimpulkan bahawa tujuan manajemen pendidikan Islam adalah bahwa segala hal dan proses-proses yang berlangsung dapat benar-benar dikelola dengan baik sehingga proses pendidikan dapat benar-benar terwujud sesuai ajaran Islam dan. upaya pencapaian tujuan pendidikan Islam dapat lebih mudah terwujud.

\section{Ciri dan Kegunaan Manajemen Pendidikan Islam}

Sebagaimana definisi yang dikemukakan oleh Muhaimin, bahwa manajemen pendidikan Islam merupakan aktivitas pendidikan yang diselenggarakan dengan hasrat 
untuk mengejawantahkan ajaran dan nilai-nilai Islam. Dalam praktiknya di indonesia pendidikan Islam setidak-tidaknya dapat dikelompokkan ke dalam lima jenis, yaitu:

a) Pondok Pesantren atau Madrasah Diniyah, yang menurut UU No. 20 Tahun 2003 tentang Sistem Pendidikan Nasional di sebut sebagai pendidikan kegamaan (Islam) formal, seperti pondok pesantren/Madrasah Diniyah (U la, wustha, 'U lya, dan Ma'had 'Ali).

b) PAUD/RA, BA, TA, Madrasah dan pendidika lanjutan seperti IAIN, STAIN atau Universitas Islam Negeri yang bernaung di bawah Kementerian Agama.

c) Pendidikan Usia dini, RA, BA, TA, sekolah/perguruan tinggi yang diselenggaraakan di bawah naungan yayasan dan organisasi Islam.

d) Pelajaran agama Islam di sekolah/madrasah/perguruan tinggi sebagai suatu mata pelajaran atau mata kuliah, dan atau sebagai program studi; dan

e) Pendidikan Islam dalam keluarga atau di tempat-tempat ibadah, dan/atau di forum-forum kajian keislaman, majelis taklim, dan institusi-institusi lainnya yang sekarang sedang digalakkan oleh masyarakat, atau pendidikan (Islam) melalui jalur pendidikan nonformal, dan informal (Muhaimin, 2010).

Dengan demikian lingkup praktik manajemen pendidikan Islam meliputi manajemen kelembagaan dan program pendidikan Islam serta aspek spirit Islam melekat pada setiap aktivitas pendidikan.

\section{Prinsip Manajemen Pendidikan Islam}

Pentingnya prinsip-prinsip dasar dalam praktik manajemen antara lain: 1) menentukan cara/metode kerja; 2) pemilihan pekerja dan pengembangan keahliannya; 3) pemilihan prosedur kerja; 4) menentukan batas-batas tugas; 5) mempersiapkan dan membuat spesifikasi tugas; 6) melakukan pendidikan dan latihan; 7) menetukan sistem dan besarnya imbalan. Semua itu dimaksudkan untuk meningkatkan efektivitas, efisiensi, dan produktivitas kerja (Fatah, 2008).

Dalam kaitannya dengan prinsip dasar manajemen, Fayol mengemukakan sejumlah prinsip seperti yang dikutip oleh Nanang Fatah, yaitu : pembagian kerja, kejelasan dalam wewenang dan tanggung jawab, disiplin, kesatuan komando, kesatuan arah, lebih memprioritaskan kepentingan umum/organisasi daripada kepentingan pribadi, pemberian kontra prestasi, sentralisasi, rantai skalar, tertib, pemerataan, stabilitas dalam menjabat, inisiatif, dan semangat kelompok. Keempat belas prinsip dasar tersebut dijadikan patokan dalam praktik manajerial dalam melakukan manajemen yang berorientasi kepada sasaran (Management by Objectives $\{\mathrm{MBO}\}$ ), manajemen yang berorientasi orang (Managemnet by People $\{\mathrm{MBP}\}$ ), manajemen yang berorientasi kepada struktur (Management by Technique $\{\mathrm{MBT}\}$ ), dan manajemen berdasarkan 
informasi (Management by Information $\{\mathrm{MBI}\}$ ) atas Management Information System \{MIS \} (Fatah, 2008).

Hendiat Soetomo dan Wasti Sumanto mengemukakan tentang prinsip Manejemen Pendidikan Dengan menganut pola administrasi pendidikan modern yang berprinsip pada demokrasi dengan ciri penghargaan terhadap potensi manusia, maka prinsip manajemen pendidikan atau sekolah hendaknya (Soetomo \& Sumanto, 1982).

a) Desentralisasi sistem dan anggota staf.

Yang dimaksud prinsip ini adalah otoritas dan tanggungjawab serta tugas yang harus didelegasikan dalam konteks kerangka kerja policy yang diadopsikan di sekolah.

b) Mempertinggi penghargaan terhadap personal

Personal yang terikat dalam unit kerja harus diperhitungkan dan dihargai oleh pimpinan yang disesuaikan dengan otoritas, dan tanggungjawab serta tujuan dan wewenang yang dilimpahkan kepada personal tersebut.

c) Perkembangan dan pertumbuhan personal sekolah secara optimal

Mengembangkan dan menumbuhkan kemampuan serta keterampilan personal secara optimal. Dengan kata lain masing-masing personal sekolah harus bisa menampilkan potensinya dengan semaksimal mungkin.

d) Perlibatan personal

Setiap personal kerja sekolah senantiasa dilibatkan dari mulai perencanaan pengorganisasian dan pengawasan sehingga semuanya menjadi tanggungjawabm bersama.

Dari beberapa pendapat diatas maka dapat ditarik suatu kesimpulan bahwa prinsip manajemen pendidikan Islam adalah pemanfataan sumber daya yang dimiliki lembaga (lembaga pendidikan atau lainnya) yang dilakukan melalui kerja sama dengan orang lain secara efisien, efektif dan produktif untuk mencapai kebahagiaan dan kesejahteraan di dunia dan di akhirat.

\section{Simpulan}

Manajemen adalah suatu usaha, merencanakan, mengorganisir, mengarahkan, mengkordinir serta mengawasi kegiatan dalam suatu organisasi agar tercapai tujuan organisasi secara efisien dan efektif. Sedangkan Pendidikan Islam dapat diartikan sebagai bimbingan terhadap pertumbuhan rohani dan jasmani menurut ajaran Islam dengan hikmah mengarahkan, mengajarkan, melatih, mengasuh dan mengawasi berlakunya semua ajaran Islam. Jadi bias disimpulkan bahwa manajemen pendidikan Islam adalah suatu proses dengan menggunakan berbagai sumber daya untuk melakukan bimbingan terhadap pertumbuhan rohani dan jasmani seseorang agar ia berkembang secara maksimal sesuai dengan ajaran Islam. 
Dasar manajemen pendidikan Islam ada dalam beberapa ayat Al-Qur'an seperti dalam surat At-Taubah ayat 122, dan dalam hadits Rasulullah SAW yang diriwayatkan oleh Ibnu Majah. Selain itu, dalam Negara Indonesia juga mengatur tentang manajemen pendidikan, yakni UU No. 20 Tahun 2003 tentang Sistem Pendidikan Nasional disebutkan dalam Pasal 30 ayat 1 dan 2 .

Tujuan manajemen pendidikan Islam adalah agar segenap sumber, peralatan ataupun sarana yang ada dalam suatu organisasi tersebut dapat digerakkan sedemikian rupa sehingga dapat menghindarkan sampai tingkat seminimal mungkin segenap pemborosan waktu, tenaga, materil, dan uang guna mencapai tujuan organisasi yang telah ditetapkan terlebih dahulu.

Ruang lingkup praktik manajemen pendidikan Islam meliputi manajemen kelembagaan dan program pendidikan Islam serta aspek spirit Islam melekat pada setiap aktivitas pendidikan. Sedangkan mengenai prinsip manajemen pendidikan Islam setidaknya ada 14, diantaranya; pembagian kerja, kejelasan dalam wewenang dan tanggung jawab, disiplin, kesatuan komando, kesatuan arah, lebih memprioritaskan kepentingan umum/organisasi daripada kepentingan pribadi, pemberian kontra prestasi, sentralisasi, rantai skalar, tertib, pemerataan, stabilitas dalam menjabat, inisiatif, dan semangat kelompok.

Diharapkan kepada segenap pembaca, khususnya akademis agar dapat lebih banyak meneliti atau punmelahirkan karya-karya tulisan terkait dengan topik permasalahan mengenai Manajemen Pendidikan Islam, demi memperkaya khasanah penulisan masalah pendidikan, yang tetap tidak dapat terpisahkan dengan perjalanan sejarah pendidikan di Indonesia. Diharapkan kepada segenap pembaca untuk dapat mengaktualisasikan nilai-nilai pada ruang lingkup praktek manajemen pendidikan Islam demi terlaksananya proses pendidikan yang optimal dan tercapai tujuan pendidikan nasional.

\section{Referensi}

Al-Mu'ajm, Al-Wajiz. Majma'ul-Lughoh al Arrabiyah. Huruf Nuun.

Departemen Agama Republik Indonesia. (2002). Al-Qur'an dan Terjemahannya. Jakarta: PT Indah Press.

Daulay, Putra, Haidar. (2004). Pendidikan Islam. Jakarta: Kencana.

Fatah, N. (2008). Landasan Manajemen Pendidikan. Bandung: PT Remaja Rosdakarya.

Manaf, H. S. (2001). Pola Manajemen Penyelenggaraan Pondok Pesantren. Jakarta: Dirjen Pembinaan Kelembagaan Agama Islam Depag Republik Indonesia.

Marribah, A.D. (1997). Pengantar Filsafat Pendidikan Islam. Jakarta: Bumi Aksara. 
Martoyo, S. (1988). Pengetahuan Dasar Manajemen dan Kepemimpinan. Yogyakarta: BPFE.

Muhaimin. (2010). Manajemen Pendidikan Islam, Aplikasinya dalam Penyusunan Rencana Pengembangan Sekolah. Jakarta: Kencana.

Qomar, M. (2008). Manajemen Pendidikan Islam. Jakarta: Erlangga.

Rivai, V. (2006). Manajemen Sumber Daya Manusia untuk Perusahaan dari Teori ke Praktek. Jakarta: Raja Grafindo Persada.

Siagian, Sodang .P. (1990). Filsafah Administrasi. Jakarta: CV. Masagung.

Soetomo, Hendiat, Sumanto, Wasti. (1982). Pengantar Operasional Administrasi Sekolah. Surabaya: Usaha Nasional.

Sulistyorini. (2006). Manajemen Pendidikan Islam. Surabaya: elKAF.

Tafsir, A. (2001). Ilmu Pendidikan dalam Perspektif Islam. Bandung: Remaja Rosda Karya.

Wahjosumidjo. (1987). Kepemimpinan dan Motivasi. Jakarta: Ghalia Indonesia.

Zuhaerini. (1983). Metodik Khusus Pendidikan Agama. Surabaya: Usaha Nasional.

Fastafiqfahmi.blogspot.com/2014/05/pengertian-manajemen-pendidikan-islam.html.

http/www.majalahpendidikan.com/2011/10fungsi-perencanaan-dalammanajemen.html.

https://mpiuika.wordpress.com/2009/10/22/makalah-diskusi-mpi-kelompok-1/.

http://kbbi.web.id/didik : Kamus Besar Bahasa Indonesia.On line.

http://www.alquran-indonesia.com/web/quran/listings/details/17/20.

http://kbbi.web.id/didik. Kamus Besar Bahasa Indonesia. On line. 